\title{
Teaching English through Stories to Chinese Primary Students
}

\author{
Xinyi Huang \\ Hunan Electromechanical Vocational and Technical College, Changsha, Hunan Province, China
}

\begin{abstract}
Due to the increase in English as a lingua franca, the Chinese government and educators are preoccupied with the demand to develop greater numbers of people who can communicate accurately and competently in English. English stories are generally not used by language teachers and are considered unsuitable in China, further, teachers fail to explain stories' content and apply traditional teaching approaches in the class.
\end{abstract}

Key words: Teaching English; Chinese Primary Students

Publication date: April, 2021; Publication online: 30 April, 2021

*Corresponding author: Xinyi Huang, 737784660@qq.com

\section{Introduction}

Due to the increase in English as a lingua franca, the Chinese government and educators are preoccupied with the demand to develop greater numbers of people who can communicate accurately and competently in English. In order to achieve this goal, the national education syllabus and policies made a decision to make English a compulsory subject in Chinese primary schools in 1970s (Hu, 2005). In order to allow pupils to achieve a good academic performance in this compulsory subject, teachers consider so many ways to help their students. Learning through stories is considered one successful way to learn English, especially for young learners. Further, teaching English through stories may offer young learners the chance to open their horizons, stimulate their early excitement as well as improve their awareness of using English (Mart 2012). Huck (1993) adds that children's literature may be seen as the imaginative shaping of our life and thoughts into the structures and patterns of language. Furthermore, stories may allow young learners to explore and understand their world and enrich their own lives (Galda and Cullinan 2002). According to Slatterly and Willis (2001), children achieve language unconsciously, therefore, the activities the teacher applies in the class should help with this kind of achievement. Certainly, stories are considered one of the most valuable materials for teachers, providing young learners with a world of supported meaning with which they can connect.

\section{Literature review}

This section offers brief introduction of learning features of young learners, as well as a critical review of using stories to teach languages to young students.

\subsection{Learning characteristics of young learners}

Compared to teaching a target language to teenagers and adults, clearly, children are equipped with their own learning features. Children are energetic and active learners but have short attention span. According to Cameron (2001), children are more enthusiastic and livelier than any other age group of students. They may even participate in activities without fully understanding why and how. Additionally, Shin and Crandall (2014) hold that children naturally tend to be physically active and that teachers should not become disappointed with the fact that young learners cannot sit in the classroom for a long time. However, studies also show that young learners are easily distracted and quickly to lose interest and are less able to keep themselves engaged in studying tasks which they feel are challenging for them (Cameron, 2001), though they do tend to pay more attention to something they feel is fun and interesting (Harmer, 2007).

Children are imaginative and curious learners. As Shin and Crandall (2014) claim, young learners are equipped with natural curiosity; they want to know more about new things in their world. Harmer (2007) shares this view that young leaners always present an enthusiasm for studying and are curious about the world around them. Further, the characteristic that children love activities, encourages them to use their natural imagination. Scott and Ytreberg (1990) also 
highlight that children have vivid imaginations and are curious, which help them to show a positive and enthusiastic attitude to learn new things. Moreover, a study by Moon (2000) shows that young students energetically try to investigate and work out the language rules in their mind, though they might not be aware that they are doing this. Activities which young learners perform in the class and the discussion afterwards allows them the freedom to be creative and go beyond what they have studied (ibid).

\subsection{Benefits of learning through stories for young learners}

There are a number of advantages of teaching young learners both the language and content used in children's stories.

\subsubsection{Advantages of story language}

It is commonly believed that literature-based instruction can make a positive difference in target language learning, especially for young learners (Morrow, 1992). As Cameron (2001) highlights, children's stories include uses of language that are seen as classic of literary texts and poetry. Many of these elements provide opportunities for target language studying. Ellis and Brewster (2002) further claim that learning the target language through story books can set the foundations for some schools for the basis of learning primary language functions and structures, language learning skills and vocabularies. Furthermore, children's stories provide natural language which advances vocabulary recognition, chances for authentic writing and reading tasks, as well as not being grammatically sequenced (Ghosn, 2002). Taguchi et al. (2016) highlight that repeated reading and auditory model reading through story may help to promote students' reading comprehension rates. Moreover, immersing pupils in narrative and linguistic conversations through story, applying storytelling and hearing story activities in the classroom may not only help students to develop language ability but also allow them to study an enjoyable experience (Fox, 1993). These story-based activities may help pupils to achieve vocabularies, providing young learners with an opportunity for more sentence constructions and syntax output (Winch, 2006). All of the characteristics of children's stories may help young learners to promote their target language acquisition.

\subsection{Challenges of learning through stories}

Teaching the target language through stories creates various demands on language teachers and for good quality books.

\subsubsection{High demand on language teachers.}

As Cameron (2001) points out, may take the form of the challenge for language teachers to select stories with content suitable for young learners and to organize activities that combine language learning and young learners learning characteristics. By doing so, language teachers need many of the skills and target language knowledge. Cameron further claims that if applying learner-centred perspective in the language learning classroom of children, it is required that the class syllabus should work clearly and effectively in the language teacher's mind. Teachers should consider how the tasks are worked and what young learners may learn from these tasks (Cameron, 2001). Furthermore, Ellis and Brewster (2002) illustrate that applying an optimal teaching methodology is also significant for language learning lessons. Thus, significant skills in organising teaching activities and language knowledge of a foreign language teacher are crucial.

\subsubsection{High demand for story books.}

Choosing a suitable story for young learners is very significant. According to Cameron (2001), stories which are equipped with the qualities of organisational structure, content and language application are considered as potentially helpful tools in the target language class, because they have the potential to engage young learner's attention and thus motivate them to study, as well provide space for language achievement. In addition, Krashen (1985) explains that comprehensive story materials are sufficiently understandable for young learners to reach their language goals. Moreover, Shin and Crandall (2014) claim that high quality stories may keep children's attention and allow them to follow along in target language without applying their native language. Additionally, Chen and Chang (2009) state that if the reading materials are too much of a challenge and too complex for young language learners, they may be discontent and lose attention in the classroom. Cameron (2001) also claims that too many new words and phrases may make the story incomprehensible. It is true that not all stories are good for language learning, the criteria for how to choose a suitable story book for young learners should be highlighted. Curtain and Dahlberg (2004) propose a series of criteria for selecting a suitable story book for young learners. They suggest all stories should:
(1) be easily predictable
(2) be familiar to the demotic environment
(3) be equipped with a high percentage of known words
(4) contain predictable and repetitive patterns
(5) offer chances to apply physical activities
(6) make better use of visual and realia to make content comprehensible. 
If stories meet these principles, then it may be possible to present perfect language learning experiences. However, if students feel it is hard to follow the story, the reason may be that the story needs to be modified to the students' language level or changed altogether (Shin and Crandall, 2014).

Therefore, choosing a suitable story book, planning an optimal class syllabus, applying appropriate teaching activities and methodologies are significant elements for bringing stories' superiority into full play.

\section{Context}

Having considered the main literature informing this study, an overview of key areas of the given primary environment should be discussed. Therefore, the following paragraphs show the features of the Chinese state primary education system and provides an overview of current application of learning language through children's stories in Chinese classes.

\subsection{Chinese state primary school}

Based on personal teaching experience of this context, there are about fifty students in every classroom. A normal lesson is approximately forty-five minutes long. Teachers in a state school commonly are non-native English speakers, however, most of them are trained, professional language teachers. The biggest difference between state school and private school is that teachers are paid by the government, not by the private companies. In a state primary school, the design of class plans is decided by different school years. For the students in the lower school years, the class syllabuses are designed to engage their interest in study. For the middle years, the curriculums are aimed at promoting learners' skills to use study knowledge. For higher school years, the lesson plans are essentially based on the secondary school entrance examination (Yang, 2001). This paper is based on personal teaching experience in the high school context. Almost all students are ten to twelve years old and can read some fullEnglish story books with teachers' scaffolding.

\subsection{Current application of learning through stories in China}

Generally speaking, the secondary school entrance examination is a grammar-based examination, so teachers will more focus on grammar in their teaching syllabus, Teachers tend to use traditional teaching approaches in their classes. However, according to secondary language acquisition, young learners are more likely to achieve language in a meaningful, enjoyable and authentic communicative context (Porras González, 2010). Thus, English teachers attempt to apply children's story books in the class to engage their students.

Normally, English teachers use stories to organise interaction activities in the warm-up part of their lessons, like storytelling. They do not generally give more time for story activities given the limited class time and grammar-driven teaching goal. Thus, stories are used at the beginning stage of a class purely for engagement. Nevertheless, with English as a lingua franca, it pervades every aspect of our life, from daily life to international communication. Further, although the benefits of teaching language through stories are widely acceptable by more and more Chinese educators, it is not enough to be using stories solely for warm-up as this no longer meets the needs of the students. Thus, in order to give students more opportunities to immerse in the English context and to better understand foreign culture, English teachers arrange story reading classes once or twice a term for primary school students. During these story reading sessions, commonly, teachers will organise twenty minutes to allow students to read the story freely, and then use the later twentyfive minutes to introduce new language knowledge, such as new grammar forms, new vocabulary and phrases. The materials in the story are decided by the English teacher themselves. Normally, teachers download the story texts from online. By adopting stories, pupils appear to be more engaged in and outside the English classes, students not only show a higher enthusiasm towards English reading classes than language knowledge introduction class, but they also like to share the English stories with their parents and friends after the reading class. However, using stories in Chinese primary schools is not always positive, there are still some limitations. This paper will discuss these challenges in the next section.

\section{Discussions}

Having considered the specific Chinese educational context and the current situation for using stories in class. This section offers some challenges of applying stories in English classes in the above context. Specifically, English stories are generally not used by language teachers and are considered unsuitable in China, further, teachers fail to explain stories' content and apply traditional teaching approaches in the class.

\subsection{Unsuitable stories used in English classes}

Selecting an inappropriate story book for their students is a key weakness for English classes in Chinese primary schools. As mentioned in the context section, materials used in story 
reading classes are currently determined by language teachers themselves, and teachers often source the materials online. What is most striking is that, some of the online stories fail to match their young learners' language level. A lot of vocabularies in these online stories are challenging for the students, therefore, it is hard for them to understand the whole meaning of these stories. Especially, in the reading classes, in which teachers are not introducing the new words and phrases at the beginning of the class, rather, they usually allow students to read by themselves and then highlight some key words and grammar for them. As Cameron (2001) points out a story may contain some new English vocabularies, but too many new words can make the story become incomprehensible. Cameron further claims that in preparing to apply story in the class, it is important to pre-teach the new vocabularies and phrases to help children better understand the meaning of stories.

\subsection{Ignoring meaningful content of story}

Another limitation is that English teachers only pay attention to language study, ignoring the actual content of stories. As aforementioned in the context area, teachers used the latter twenty-five minutes in reading classes to introduce some language knowledge to students. While, at this stage, grammar structure study occupies a large percentage of time, there then follows the study of new vocabulary and phrases. Almost all teachers fail to explain the meaning of story materials to their students. Additionally, some stories are difficult for young learners to understand if they know little about the story background, especially in relation to some foreign classic stories, such as some stories involving foreign history (Cameron, 2001). The reasons why teachers prefer language teaching is the specific grammar-based examination system. Further, time available is a consideration with limited class time; if teachers were to spend more time on explaining the content and background of a story, there would be less time for them to teach the language knowledge. In order to help their students to achieve a good academic performance in the examination, language teachers have no choice but to focus more on grammar teaching in China. However, just focusing on language acquisition is not the purpose of using stories in language classes. Stories are not simply used to help students to foster language ability but offer young learners a good opportunity to open their horizons, stimulate students' enthusiasm and develop their awareness of the rich use of target language (Mart, 2012). Furthermore, some human condition achieved only through the story's meaningful content, for example the content of story may contribute to students' emotional development and foster positive interpersonal and intercultural attitudes (Ghosn, 2002). Moreover, as aforementioned, stories are a metaphor for our world offering some deeper understanding of human society (Ellis and Brewster, 2002). It is difficult for young learners to achieve this deeper meaning of stories without teachers' scaffolding.

\section{References}

[1] Amer, A. A. (2003). Teaching efl/esl literature. The Reading Matrix, 3(2).

[2] Bettelheim, B. (2010). The uses of enchantment: The meaning and importance of fairy tales. Vintage.

[3] Burwitz-Melzer, E. (2001). Teaching intercultural communicative competence through literature. Developing intercultural competence in practice, 29-43.

[4] Cameron, L. (2001). Teaching languages to young learners. Ernst Klett Sprachen.

[5] Chen, I., \& Chang, C. C. (2009). Cognitive load theory: An empirical study of anxiety and task performance in language learning.

[6] Curtain, H. A., \& Dahlberg, C. A. (2004). Languages and children, making the match: New languages for young learners. Allyn \& Bacon.

[7] Ellis, G., \& Brewster, J. (2002). The primary English teacher's guide / Gail Ellis and Jean Brewster. (New ed., Penguin English guides). Harlow.

[8] Fox, C. (1993). At the very edge of the forest: The influence of literature on storytelling by children. Burns $\&$ Oates.

[9] Galda, L., \& Cullinan, B. E. (2002). Cullinan and Galda's literature and the child (Vol. 1). Wadsworth Publishing Company.

[10] Ghosn, I. K. (2002). Four good reasons to use literature in primary school ELT. ELT journal, 56(2), 172-179.

[11] Goleman, D. (2006). Emotional intelligence. Bantam.

[12] Harmer, J. (2007). The practice of English language teaching / Jeremy Harmer. (4th ed.). Harlow.

[13] Hu, G. (2005). English language education in China: Policies, progress, and problems. Language policy, 4(1), 5-24.

[14] Huck, C. S. (1993). Children's literature in the elementary school. Harcourt Brace, 6277 Sea Harbor Drive, Orlando, FL 32887. 
[15] Krashen, S. D. (1985). The input hypothesis: Issues and implications. Addison-Wesley Longman Ltd.

[16] Mart, C. T. (2012). Encouraging Young Learners to
Learn English through Stories. English Language Teaching, 5(5), 101-106. 